IRA-International Journal of Education \& Multidisciplinary Studies

ISSN 2455-2526; Vol.08, Issue 01 (July 2017)

Pg. no. 1-10

Institute of Research Advances

http://research-advances.org/index.php/IJEMS

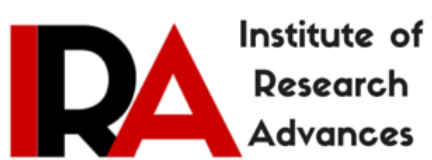

\title{
Gender Based Correlational Study between Multiple Intelligence and Emotional Intelligence
}

\author{
Surbhi Agarwal \\ Research Scholar, Department of Education, CCS University, Meerut, India. \\ Prof. Suraksha \\ Department of Education, CCS University, Meerut, India.
}

Type of Review: Peer Reviewed.

DOI: http://dx.doi.org/10.21013/jems.v8.n1.p1

\begin{abstract}
Agarwal, S., \& Suraksha (2017). Gender Based Correlational Study between Multiple Intelligence and Emotional Intelligence. IRA International Journal of Education and Multidisciplinary Studies (ISSN 24552526), 8(1), 1-10. doi:http://dx.doi.org/10.21013/jems.v8.n1.p1
\end{abstract}

(C) Institute of Research Advances.

\section{(cc) BY-No}

This work is licensed under a Creative Commons Attribution-Non Commercial 4.0 International License subject to proper citation to the publication source of the work.

Disclaimer: The scholarly papers as reviewed and published by the Institute of Research Advances (IRA) are the views and opinions of their respective authors and are not the views or opinions of the IRA. The IRA disclaims of any harm or loss caused due to the published content to any party.

Institute of Research Advances is an institutional publisher member of Publishers Inter Linking Association Inc. (PILA-CrossRef), USA. The institute is an institutional signatory to the Budapest Open Access Initiative, Hungary advocating the open access of scientific and scholarly knowledge. The Institute is a registered content provider under Open Access Initiative Protocol for Metadata Harvesting (OAI-PMH).

The journal is indexed \& included in WorldCat Discovery Service (USA), CrossRef Metadata Search (USA), WorldCat (USA), OCLC (USA), Open J-Gate (India), EZB (Germany) Scilit (Switzerland), Airiti (China), Bielefeld Academic Search Engine (BASE) of Bielefeld University, Germany, PKP Index of Simon Fraser University, Canada. 


\begin{abstract}
The study aims to find the relationship between male and female students at senior secondary level corresponding to their multiple intelligence and emotional intelligence. A sample of 250 boys and 250 girls studying in four senior secondary schools of Meerut city was randomly selected. Multiple Intelligence scale by the investigator herself and Emotional Intelligence Scale by Arun Kumar \& Prof. Suraksha was used. Difference between male and female students corresponding to their relationship between multiple intelligence and emotional intelligence was determined by applying product moment correlation and significance of $r$ (referred by H.E. Garret). After analysis of data it was found that there exists no significant relationship between male and female students with reference to multiple intelligence and emotional intelligence.
\end{abstract}

Keywords: Multiple intelligence, emotional intelligence, gender

\title{
Introduction
}

The concept of multiple intelligence was given by Prof. Howard Gardner in 1983. There are nine dimensions of multiple intelligence according to Howard Gardner.

1. Linguistic intelligence ("word smart") is the ability to use words and language. It is the ability to think in words rather than pictures. It develops high auditory skills and elegant speaking.

2. Logical-mathematical intelligence ("number/reasoning smart") is the ability to use reason, logic and numbers. It is the ability to think conceptually in logical and numerical patterns making connections between pieces of information. It develops curiosity about the world around, asking lots of questions and liking to do experiments.

3. Spatial intelligence ("picture smart") is the ability to perceive the visual. It is the ability to think in pictures and need to create vivid mental images to retain information. It develops enjoyment looking at maps, charts, pictures, videos, and movies.

4. Bodily-Kinesthetic intelligence ("body smart") is the ability to control body movements and handle objects skillfully. It is the ability to express through movement. It develops a good sense of balance and eye-hand coordination. (e.g. ball play, balancing beams). It is the ability to remember and process information through interacting with the space around.

5. Musical intelligence ("music smart") is the ability to produce and appreciate music. It is the ability to think in sounds, rhythms and patterns. It develops immediate response to music either appreciating or criticizing whatever is heard. It develops extremely sensitivity to environmental sounds (e.g. crickets, bells, dripping taps).

6. Interpersonal intelligence ("people smart") is the ability to relate and understand others. It is the ability to see things from other people's point of view in order to understand how they think and feel. It is the ability to use both verbal (e.g. speaking) and non-verbal language (e.g. eye contact, body language) to open communication channels with others. It develops an uncanny ability to sense feelings, intentions and motivations. It develops great organizers, although they sometimes resort to manipulation. It develops to maintain peace in group settings and encourage co-operation.

7. Intrapersonal intelligence ("self smart") is the ability to self-reflect and be aware of one's inner state of being. It is the ability to understand inner feelings, dreams, relationships with others, and strengths and weaknesses.

8. Naturalistic intelligence ("nature smart") is the ability to discriminate among living things as well as sensitivity to other features of the natural world namely clouds, rock configurations, insects, fossils, butterflies, feathers, shells or dinosaurs etc. It is the expertise in the observation, recognition, classification and collection of plants and animals.

9. Existential intelligence ("cosmic smart") is the ability to be sensitive to, or have the capacity for, conceptualizing or tackling deeper or larger questions about human existence, such as the meaning of life, why are 
we born, why do we die, what is consciousness, or how did we get here. It is called "wondering smart", "cosmic smart", "spiritually smart" or "metaphysical intelligence".

\section{Emotional Intelligence:}

Emotional intelligence (E.I.) is defined as comprising abilities such as "...getting along with others, self-motivation, persistence, controlling impulses, empathizing, and regulating one's moods". Goleman (1995)

Literature suggests that emotional intelligence and multiple intelligence of an individual are correlated with each other. Present study is undertaken to further explore the relationship between male and female students corresponding to their multiple intelligence and emotional intelligence.

\section{Review of related literature}

\section{Studies related to multiple intelligence and emotional intelligence}

Shearer, Branton C.(2006) explored the relationship among the multiple intelligences and emotional intelligence. The article described the relationship between an assessment for the multiple intelligences (Gardner, 1993; Shearer, 1996) and emotional intelligence (Goleman, 1995; BarOn, 1997). Participants were 31 university undergraduates in a career exploration class and 54 doctoral education adults. Correlations ranged from very low to moderate in a pattern that is theoretically consistent with multiple intelligences theory. It was concluded that emotional competence is appropriately identified as a subset of the Intrapersonal and Interpersonal intelligences.

\section{Statement of aim}

"To study the relationship between male and female students at senior secondary level corresponding to their multiple intelligence and emotional intelligence."

\section{Objective of study}

1.To study relationship between male and female students corresponding to multiple intelligence and emotional intelligence.

\section{Hypothesis of study}

H1: There is no significant relationship between male and female students with reference to multiple intelligence and emotional intelligence.

Here, 9 sub-hypotheses have been formulated due to nine dimensions of multiple intelligence to study and analyze the data.

\section{Sub-Hypotheses:}

1.1. There is no significant relationship between male and female students corresponding to linguistic intelligence and emotional intelligence.

1.2. There is no significant relationship between male and female students corresponding to logical intelligence and emotional intelligence.

1.3. There is no significant relationship between male and female students corresponding to bodily-kinesthetic intelligence and emotional intelligence.

1.4. There is no significant relationship between male and female students corresponding to musical intelligence and emotional intelligence.

1.5. There is no significant relationship between male and female students corresponding to spatial intelligence and emotional intelligence.

1.6. There is no significant relationship between male and female students corresponding to naturalistic intelligence and emotional intelligence. 
1.7. There is no significant relationship between male and female students corresponding to interpersonal intelligence and emotional intelligence.

1.8. There is no significant relationship between male and female students corresponding to intrapersonal intelligence and emotional intelligence.

1.9. There is no significant relationship between male and female students corresponding to existential intelligence and emotional intelligence.

\section{Methodology}

Method of the study: Descriptive survey method was used to study the emotional intelligence and multiple intelligence of male and female students.

Sample: A sample of 250 boys and 250 girls studying in four secondary schools of Meerut city was selected on random basis for the study. The sample was equal on age and socio-economic status.

Tools used in the study: Multiple intelligence scale (Surbhi Agarwal, Prof. Suraksha) prepared by the investigator herself and Emotional Intelligence Scale (Arun Kumar, Prof. Suraksha) was used in the study.

\section{Statistical techniques used}

Product moment correlation and significance of correlation (referred by H.E. Garret) were applied to see the significant relationship between variables.

\section{Analysis of the data}

\section{Testing of Hypothesis}

Hypotheses 1: states that There is no significant relationship between male and female students with reference to multiple intelligence and emotional intelligence.

The results of testing of hypothesis framed to study relationship between multiple intelligence and emotional intelligence are shown in table 1.0.

Table 1.0: Relationship between male and female students corresponding to multiple intelligence and emotional intelligence

\begin{tabular}{|l|l|l|l|}
\hline Correlation between & $\begin{array}{c}\text { Male students } \\
(\mathbf{N}=\mathbf{2 5 0})\end{array}$ & $\begin{array}{c}\text { Female students } \\
(\mathbf{N}=\mathbf{2 5 0})\end{array}$ & Significance of ' $\mathbf{r}$ ' \\
\hline $\begin{array}{l}\text { Multiple intelligence and } \\
\text { emotional intelligence }\end{array}$ & 0.089 & 0.127 & 0.5 \\
\hline
\end{tabular}

The above table 1.0 shows that the significance of correlation between male and female students $(\mathrm{N}=500)$ came out to be 0.5 which is positive and insignificant. So null hypothesis has been accepted. It indicates that there exists no significant relationship between male and female students.

As this hypothesis has 9 sub-hypotheses, the analysis has been conducted accordingly.

Table 1.1 shows the results for the dimensions of multiple intelligence and emotional intelligence.

Table 1.1: Relationship between male and female students corresponding to dimensions of multiple intelligence and emotional intelligence

\begin{tabular}{|l|c|c|c|}
\hline Correlation between & Male students & Female students & Significance of 'r' \\
\hline
\end{tabular}




\begin{tabular}{|l|c|c|c|}
\hline & $\mathbf{( N = 2 5 0 )}$ & $\mathbf{( N = 2 5 0 )}$ & $2 * *$ \\
\hline $\begin{array}{l}\text { 1.Linguistic intelligence and emotional } \\
\text { intelligence }\end{array}$ & 0.098 & -0.078 & $3.02^{*}$ \\
\hline $\begin{array}{l}\text { 2.Logical intelligence and emotional } \\
\text { intelligence }\end{array}$ & 0.028 & 0.264 & 1.72 \\
\hline $\begin{array}{l}\text { 3.Bodily-Kinesthetic intelligence and } \\
\text { emotional intelligence }\end{array}$ & 0.10 & -0.038 & $4.1^{*}$ \\
\hline $\begin{array}{l}\text { 4.Spatial intelligence and emotional } \\
\text { intelligence }\end{array}$ & 0.091 & -0.237 & $20.3^{*}$ \\
\hline $\begin{array}{l}\text { 5. Musical intelligence and emotional } \\
\text { intelligence }\end{array}$ & -0.034 & 0.918 & $2^{* *}$ \\
\hline $\begin{array}{l}\text { 6. Naturalistic intelligence and emotional } \\
\text { intelligence }\end{array}$ & 0.255 & 0.109 & $4.5^{*}$ \\
\hline $\begin{array}{l}\text { 7. Interpersonal intelligence and emotional } \\
\text { intelligence }\end{array}$ & 0.149 & -0.228 & 1.5 \\
\hline $\begin{array}{c}\text { 8. Intrapersonal intelligence and emotional } \\
\text { intelligence }\end{array}$ & -0.211 & -0.09 & 0.07 \\
\hline $\begin{array}{c}\text { 9. Existential intelligence and emotional } \\
\text { intelligence }\end{array}$ & -0.048 & -0.042 & \\
\hline
\end{tabular}

*Significant at $0.05,0.01$ level of significance

** Significant at 0.05 level of significance

Table 1.1 reveals that significance of correlation values between linguistic intelligence, logical intelligence, spatial intelligence, musical intelligence, naturalistic intelligence, interpersonal intelligence with respect to emotional intelligence have come out to be significant. Therefore, the respective null hypotheses are rejected which means male and female students show relationship with each other on aforesaid dimensions of intelligence.

The hypotheses for bodily-kinesthetic intelligence, intrapersonal intelligence and existential intelligence have not come out to be significant. Therefore, null hypotheses are accepted. It indicates that male and female students do not show relationship between the above dimensions.

However, the analysis of significance of ' $r$ ' shows that

- Male students show higher values of correlation between linguistic, bodily-kinesthetic, spatial, naturalistic, interpersonal intelligence and emotional intelligence than female students.

- Female students show higher values of correlation between logical, musical intelligence, intrapersonal intelligence and emotional intelligence than male students.

\section{Discussion of results:}

Study found that there exists no significant relationship between male and female students with reference to multiple intelligence and emotional intelligence. It can be further concluded that there is no effect of correlation between multiple intelligence and emotional intelligence of male students on female students.

Results revealed that coefficients of correlation ' $r$ ' between linguistic, logical, bodily-kinesthetic, spatial, musical, naturalistic, interpersonal intelligence and emotional intelligence of male and female students differ significantly. Male students are showing higher values of ' $r$ ' between linguistic, bodily-kinesthetic, spatial, naturalistic, interpersonal intelligence and emotional intelligence as compared to female students. Female students show higher values of ' $r$ ' between logical, musical, intrapersonal intelligence and emotional intelligence than male students. Study results appear to be genuine as males are generally found having stout body, are much aware about external environment, show more knowledge about directions, maps etc. and better in conversation with people socially as compared to female students while female studentswith emotional intelligence show more logical, musical and intrapersonal intelligence. 
It can be further concluded that higher is the correlation values of linguistic, bodily-kinesthetic, spatial, naturalistic, interpersonal intelligence and emotional intelligence among male students higher will be the correlation among female students as these are showing significant relationship between them. There exists no relationship between bodily-kinesthetic, intrapersonal, existential intelligence and emotional intelligence of male and female students. It means that male students are independent from female students on these variables.

\section{References:}

1. Abdi, Ali; Laei, S. \&Ahmadyan, H. (2013). The Effect of Teaching Strategy Based on Multiple Intelligences on Students' Academic Achievement in Science Course. Universal Journal of Educational Research, 1(4), 281-284.

2. Abdi, Ali \&Rostami, M. (2012). The Effect Multiple Intelligences- Based Instruction on Student's Creative Thinking ability at $5^{\text {th }}$ Grade in Primary School. Procedia-Social and Behavioral Sciences, 47, 105-108.

3. Ahanbor, Zahra \&Sadighi, Firooz (2010). The Relationship between Multiple Intelligences, Learning Styles and Gender. Modern Journal of Language Teaching Methods. 3(2).

4. Al-Faoury, H. O. \&Smadi, M. O. (2015). The Effect of an Integrative Skills Program on Developing Jordanian University Students' Select Multiple Intelligences. Theory and Practice in Language Studies, $5(1)$.

5. Alghamdi, F. (2014). The role of Trait Emotional Intelligence in Individual Performance: A descriptive Study in Albana University, Saudi Arabia. Journal of Service Science and Management, 7(5), 361-367.

6. Armstrong, Thomas. (2009). Multiple Intelligences in the Classroom $3^{\text {rd }}$ ed. Alexandria, VA: Association for Supervision and Curriculum Development.

7. Asthana, S.H. \&Bhushan, Braj (2007). Statistics for Social Sciences.New Delhi : PHI Private Limited.

8. Atkin, M.J. (2006). Research styles in science education. Journal of Research in Science Teaching, 5(4), 338-345.

9. Beasley, K. (1987). The Emotional Quotient. Mensa, May 1987, p25.

10. Beldoch, M. (1964), Sensitivity to expression of emotional meaning in three modes of communication, in J. R. Davitz et al.,The Communication of Emotional Meaning, McGraw-Hill, pp. 31-42

11. Best, J.W. (1961), Research in Education. New York: Prentice Hall Inc.

12. Boyatzis, R., Goleman, D. \& Rhee, K. (2000). Clustering competence in emotional intelligence: insights from the emotional competence inventory (ECI). In R. Bar-On \& J.D.A. Parker (eds.): Handbook of emotional intelligence (pp. 343-362). San Francisco: Jossey-Bass.

13. Boyatzis, R. et al. (2008) "A 20-year view of trying to develop emotional, social and cognitive intelligence competencies in graduate management education." Journal of Management Development, 27(1), 92-108.

14. Brackett M. A. et al. (2011).Emotional Intelligence: Implications for Personal, Social, Academic, and Workplace Success. Social and Personality Psychology Compass, 5(1), 88-103.

15. Bradberry, Travis and Greaves, Jean. (2009). Emotional Intelligence 2.0 . San Francisco: Publishers Group West. ISBN 978-0-9743206-2-5

16. Cherniss C. et al. (2006). Emotional Intelligence: What Does the Research Really Indicate?. Educational Psychologist, 41(4), 239-245.

17. Coleman, Andrew (2008). A Dictionary of Psychology (3 ed.). Oxford University Press. ISBN 9780199534067

18. Day, L. Arla \&Caroll, A. Sarah (2004). Using an ability based measure of emotional intelligence to predict individual performance, group performance, and group citizenship behaviours. Personality and Individual Differences, 36(6), 1443-1458.

19. Downey, A. L. et al. (2010). Investigating the mediating effects of emotional intelligence and coping on problem behaviours in adolescents. Australian Journal of Psychology, 62(1), 20-29.

20. Ebel, R.L., Frisbie, D.A. (1991). Essentials of educational measurement. $5^{\text {th }}$ edition, Prentice hall of India Pvt. Ltd., New Delhi. 
21. Fallahzadeh H.(2011). The relationship between emotional intelligence and academic achievement in medical science students in Iran. Procedia-Social and Behavioural Sciences, 30, 1461-1466.

22. Gardner, Howard. (1983). Frames of Mind: The Theory of Multiple Intelligences. New York: Basic Books.

23. Gardner, H. (1984). Assessing Intelligences: A Comment on Testing Intelligence without IQ Tests.The Phi Delta Kappan, 65, 699-700.

24. Gardner, H. (1995). Reflections on Multiple Intelligences: Myths and Messages. The Phi Delta Kappan, 77, 200-203 and 206-209.

25. Gardner, H. \& Moran, S. (2006). The science of multiple intelligences theory: a response to Lynn waterhouse. Educational Psychologist. 4(4), 227-232.

26. Giles, E., Pitre S., Womack, S. (2005). Multiple Intelligences and Learning Styles. Emerging Perspectives on Learning, Teaching and Technology.

27. Gardner, L., Stough, C. (2002). "Examining the relationship between leadership and emotional intelligence in senior level managers." Leadership \& Organization Development Journal, 23(2), 68-78.

28. Gardner, H., \& Hatch, T.; Hatch (1989). "Multiple intelligences go to school: Educational implications of the theory of multiple intelligences." Educational Researcher 18 (8): 4.

29. Gardner, Howard. (1993). Multiple Intelligences: The Theory in Practice. New York: Basic Books.

30. Gardner, H. (1999). Intelligence reframed: Multiple intelligence for the $21^{\text {st }}$ century. New York: Basic Books.

31. Gardner, Howard. (2000). Intelligence Reframed: Multiple Intelligences for the 21st Century. New York: Basic Books.

32. Gardner, Howard (2002). "Interpersonal Communication amongst Multiple Subjects: A Study in Redundancy." Experimental Psychology.

33. Gardner, H. (2004), Changing Minds: The art and science of changing our own and other people's minds, Harvard Business School Press, ISBN 1422103293

34. Gardner, J.K.Dr. \& QualterParnela (2010). Concurrent and incremental validity of three trait emotional intelligence measures. Australian Journal of Psychology, 62(1), 5-13.

35. Garret, H.E. \& Woodworth, R.S. (1985). Statistics in psychology and education. Bombay: Vakils, Feffer and Simons Pvt. Ltd.

36. Giles, E. et al. Multiple Intelligences and Learning Styles. Emerging Perspectives on Learning, Teaching and Technology.

37. Gilman, Lynn (2012). The Theory of Multiple Intelligence". Indiana University. Retrieved 14 November 2012.

38. Goleman, Daniel (1995). Emotional Intelligence: Why it can matter more than IQ, New York: Bantom Books.

39. Goleman, D. (1998). Working with emotional intelligence . New York: Bantam Books

40. Goleman, D. (1998), Working with Emotional Intelligence

41. Goleman, D. (2006), Social Intelligence: The New Science of Human Relationships

42. Goleman, D. (2011). The Brain and Emotional Intelligence: New Insights

43. Goleman, D. (2011). Leadership:The Power of Emotional Intelligence

44. Good, C.V. (1959). Dictionary of education. McGraw Hill Company, New York.

45. Guignon, A. (1998). Multiple Intelligences: A Theory for Everyone.Education World. Online Posting. Retrieved November 6, 2009. www.education-world.com.

46. Guilford, J.P. (1956). Fundamental statistics in psychology and education. New York: Mcgraw Hill Book Company.

47. Gupta, Sachin, (2014). Research Paper on Emotional Intelligence and Work life balance of Employees in the Information Technology Industry. Social Science Research Network. http://ssrn.com/abstract=2395216.

48. J.C. Xie \& R.L.Lin (2009). Research on Multiple Intelligences Teaching and Assessment. Asian Journal of Management and Humanity Sciences, 4(2-3), 106-124.

49. Jordan, J.P., Ashkanasy, N.M. and Hartel, J.E.C. (2002). Emotional Intelligence as a Moderator of Emotional and Behavioral Reactions to Job Insecurity. Academy of Management Review, 27(3), 361-372. 
50. Jr. M O'Connor, Raymond \& Little, S. Ian (2003). Revisiting the predictive validity of emotional intelligence: self-report versus ability-based measures. Personality and Individual Differences, 35(8), 18931902.

51. Kassell, C. (1998). Music and the Theory of Multiple Intelligences. Music Educators Journal, 84, 29-32 and 60.

52. Kaul, L. (1997). Methodology of educational research. Vikas publishing house, Delhi.

53. Kezar, A. (2001). Theory of multiple intelligences: implications for higher education. Innovative Higher Education, 26(2), 141-154.

54. Kirk, A.B.; Hine W.D. \&Schutte S. N. (2011). The effect of an Expressive-Writing Intervention for Employees on Emotional Self-Efficacy, Emotional Intelligence, Affect, and Workplace Incivility. Journal of Applied Social Psychology, 41(1), 179-195.

55. Kluemper, D.H. (2008). "Trait emotional intelligence: The impact of core-self evaluations and social desirability", Personality and Individual Differences,44 (6): 1402-1412. Doi: 10.1016/j.pais.2007.12.008.

56. Kouhdasht, N. Reza et al (2013). The relationship between Emotional Intelligence and Thinking Styles in Male and Female Students in Tehran, Iran. International Journal of Learning \& Development. 3(3), 21644063.

57. Koveshnikov, A., Wechtler, H. \&Dejoux, C. (2014). Cross- cultural adjustment of expatriates: The role of emotional intelligence and gender. Journal of World Business, 49, 362-371.

58. Kothari, C.R. (2004). Research methodology: Methods and techniques. New Delhi:New Age International Pvt . Ltd.

59. Lantieri, L, and Goleman, D. (2008), Building Emotional Intelligence: Techniques to Cultivate Inner Strength in Children.

60. Law, S. Kenneth; Wong, Chi-Sum \& Song, Lynda J. (2004). The Construct and Criterion Validity of Emotional Intelligence and its Potential Utility for Management Studies. Journal of Applied Psychology, 89(3), 483-496.

61. Leuner, B (1966). "Emotional Intelligence and emancipation". Praxis der Kinderpsychologie und Kinderpsychiatrie 15:193-203.

62. Loori, A.A. (2005). Multiple intelligences: a comparative study between the preferences of males and females. Social Behavior and Personality, 33(1), 77-88.

63. Lunenburg, C.F. \& Lunenburg, R. M. (2014). Applying Multiple Intelligences in the Classroom: A Fresh Look at Teaching Writing. International Journal Of Scholarly Academic Intellectual Diversity, 16(1).

64. MacCann, C.; Joseph, D.L.; Newman, D.A.; Roberts, R.D. (2014). "Emotional intelligence is a secondstratum factor of intelligence: Evidence from hierarchical and bifactor models". Emotion 14: 358-374

65. Mangal, S.K. (2002). Advanced Educational Psychology. New Delhi: PHI Learning Private Limited.

66. Mangal, S. K. (2010). Statistics in Psychology and Education. New Delhi: PHI Learning Private Limited.

67. Mayer, D. J. and Salovey, P. (1993). The intelligence of emotional intelligence. Intelligence, 17(4), 433442.

68. Mayer, D. John and Geher, Glenn (1996). Emotional intelligence and the identification of emotion. Intelligence, 22(2), 89-113.

69. Mayer, J.D. \&Salovey, P. (1997). What is emotional intelligence? In P. Salovey\& D. Sluyter (Eds.), Emotional development and emotional intelligence: Implications for educators (pp. 3-31). New York: Basic Books.

70. Mayer, D. John; Caruso, R. David \&Salovey Peter (1999). Emotional intelligence meets traditional standards for an intelligence. Intelligence, 27(4), 267-298.

71. Mayer, J.D.; Salovey, P.; Caruso, D.L.; Sitarenios, G. (2001). "Emotional intelligence as a standard intelligence". Emotion 1: 232-242.

72. Mayer, J.D.; Salovey, P.; Caruso, D.R.; Sitarenios, G. (2003). "Measuring emotional intelligence with the MSCEIT V2.o". Emotion 3: 97-105. 
73. Mayer, D. John; Salovey, Peter \& Caruso, R. David (2004). Emotional Intelligence: Theory, Findings, and Implications. Psychological Inquiry, 15(3), 197-215.

74. McClaskey, J. (1995). Assessing Student Learning through Multiple Intelligences. The English Journal, 84, 56-59.

75. McKenzie, W. (2005). Multiple intelligences and instructional technology. ISTE (International Society for Technology Education). ISBN 156484188

76. Milao, C., Humphrey, R.H., \& Qian, S. (2016). Leader emotional intelligence and subordinate job satisfaction: A meta-analysis of main, mediator, and moderator effects. Personality and individual Differences, 102, 13-24.

77. Oxford Advanced Learner Dictionary (1999). $5^{\text {th }}$ Edition, London.

78. Palmer B. et al. (2001). Emotional intelligence and effective leadership. Leadership \& Organization Development Journal, Vol. 22(1), 5-10.

79. Parera, N. H. \&DiGiacomo Michelle (2015). The role of trait emotional intelligence in academic performance during the university transition: An integrative model of mediation via social support, coping, and adjustment. Personality and individual Differences, 83, 208-213.

80. Parke, M.R., Seo, M.G., \&Sherf, E.N. (2015). Regulating and facilitating: The role of emotional intelligence in maintaining and using positive effect for creativity. Journal of Applied Psychology, 100(3), 917-934.

81. Parker, A.D. James et al. (2004). Emotional intelligence and academic success: examining the transition from high school to university. Personality and Individual Differences, 36(1), 163-172.

82. Perez, J.C,; Petrides, K.V. \&Fumham, A. (2005). Measuring trait emotional intelligence. In R. Schulze and R.D. Roberts (Eds.), International Handbook of Emotional Intelligence (pp. 181-201). Cambridge, MA: Hogrefe\& Huber.

83. Petrides, Konstantin; Furnham, Adrian (2001), "Trait Emotional Intelligence: Psychometric Investigation with Reference to Established Trait Taxonomies", European Journal of Personality: 425-448

84. Petrides, K.V.; Fumham, A. (2003). "Trait emotional intelligence: behavioral validation in two studies of emotion recognition and reactivity to mood induction". European Journal of Personality, 17(1), 39-75.

85. Petrides, K.V. \&Fumham Adrian (2006). The role of Trait Emotional Intelligence in a Gender-Specific Model of Organizational Variables. Journal of Applied Social Psychology, 36(2), 552-569.

86. Petrides, K.V. ; pita, R.; Kokkinaki, F. (2007). "The location of trait emotional intelligence in personality factor space". British Journal of Psychology, 98(2), 273-289.

87. Rode, C.J. et al. (2006). Emotional Intelligence and individual performance: evidence of direct and moderated effects. Journal of Organizational Behavior, 28(4), DOI: 10.1002/job.429.

88. Salovey, P.; Mayer, J. D. (1989). "Emotional intelligence". Imagination, Cognition and Personality 9 (3): 185-211.

89. Salovey, Peter; Mayer, John; Caruso, David (2004), "Emotional Intelligence: Theory, Findings, and Implications", Psychological Inquiry: 197-215

90. Salovey, P.; Grewal, D (2005). "The Science of Emotional intelligence". Current directions in psychological science, 14( 6), 281-285.

91. Shearer, Branton C. (2006). Exploring the relationship among the Multiple Intelligences and Emotional Intelligence. Multiple intelligences and Emotional intelligences.

92. Smith, M.K. (2002). "Howard Gardner, multiple intelligences and education", The Encyclopedia of informal Education

93. Suhaimi, A. W. et al. (2014). The relationship between Emotional Intelligence and Interpersonal Communication skills in disaster management context : A proposed framework. Procedia-Social and Behavioural Sciences, 155(6), 110-114.

94. Visser, Beth A.; Ashton, Michael C.; Vernon, Philip A. (2006). g and the measurement of Multiple Intelligences: A response to Gardner. Intelligence 34 (5): 507-510.

95. Waterhouse, Lynn (2006). Multiple intelligences, the Mozart Effect, and Emotional Intelligence: A Critical Review. Educational Psychologist, 47(4), 207-225. 
96. Wechsler, D., Wechsler Scale of Intelligence, (WAIS, WISE), New York: Psychological Corporation, 1939.

97. Xie, J.C., Lin, R.L. (2009). Research on Multiple Intelligences Teaching and assessment. Asian Journal of Management and Humanity Sciences,4(2-3), 106-124. 